\title{
Efficiency and Losses Analysis of Steam Air Heater from Marine Steam Propulsion Plant
}

\author{
Josip Orović $^{1, *(\mathbb{D}, \text { Vedran Mrzljak }}{ }^{2}$ and Igor Poljak ${ }^{1}$ (]) \\ 1 Maritime Department, University of Zadar, Mihovila Pavlinovića 1, 23000 Zadar, Croatia; ipoljak1@unizd.hr \\ 2 Faculty of Engineering, University of Rijeka, Vukovarska 58, 51000 Rijeka, Rijeka; vmrzljak@riteh.hr \\ * Correspondence: jorovic@unizd.hr; Tel.: +385-98-174-5205
}

Received: 1 October 2018; Accepted: 29 October 2018; Published: 2 November 2018

\begin{abstract}
Air heaters are commonly used devices in steam power plants. In base-loaded conventional power plants, air heaters usually use flue gases for air heating. In this paper, the air heater from a marine steam propulsion plant is analyzed, using superheated steam as a heating medium. In a marine propulsion plant, flue gases from steam generator are not hot enough for the air heating process. In a wide range of steam system loads, the analyzed steam air heater has low energy power losses and high energy efficiencies, ranging from $98.41 \%$ to $99.90 \%$. Exergy analysis of the steam air heater showed that exergy destruction is quite high, whereas exergy efficiency ranged between $46.34 \%$ and $67.14 \%$. Air heater exergy destruction was the highest, whereas exergy efficiency was the lowest at the highest steam system loads, which was an unexpected occurrence because the highest loads can be expected in the majority of marine steam plant operations. The change in the ambient temperature significantly influences steam air heater exergy efficiency. An increase in the ambient temperature of $10^{\circ} \mathrm{C}$ reduces analyzed air heater exergy efficiency by $4.5 \%$, or more, on average.
\end{abstract}

Keywords: steam air heater; energy power losses; energy efficiency; exergy destruction; exergy efficiency

\section{Introduction}

During the energy and exergy analysis of steam generators, regardless of the steam plant type, it is important to measure the temperature and pressure of the air that enters the steam generator combustion chamber. These operational data are essential elements for obtaining correct steam generator efficiencies in one or more operating regimes. Therefore, numerous researchers have used air operating data as a calculation input in steam generator analysis [1-3]. Scientific and professional literature have rarely presented air preparation systems and their analysis (primarily air temperature increase) before air entrance into the steam generator [4,5]. Uysal et al. [6] included an air preparation system for a steam generator in a coal-fired steam power plant located in Turkey.

In general, air heaters can be divided into two groups: flue gas air heaters where flue gases are the heating medium, and steam air heaters where steam is the heating medium [7]. Air heaters that operate with flue gases can be classified into three types: tubular, regenerative, and with heat pipes. In tubular air heaters, air or flue gases flow inside the tubes. At the cold end of tubular air heaters, low-temperature corrosion may appear, which is a major problem faced by air heaters of this type. Some of the producers use Corten steel tubes in order to minimize low-temperature corrosion [8]. Regenerative air heaters can be divided into two types: those in which the heater matrix rotates (Ljungstrom), and those in which the air and flue gas duct rotate (Rothemuelle). From the flue gases, energy is transferred to the rotating matrix that is used as a heat absorber. Absorbed heat is then transferred to the cold air during the matrix rotation [9]. This type of regenerative air heater can experience problems with ash deposits in coal-fired steam generators [10]. Air heaters with heat pipes consist of a tube bundle. Tubes are filled with an operating fluid, such as toluene or naphthalene. 
Flue gases cause evaporation of the operating fluid collected in the lower end of the slightly inclined pipes. The operating fluid vapor flows to the condensing section where vapor transfers the heat to the incoming air. The condensed operating fluid returns to the evaporator by gravity. As long as a temperature difference exists between the flue gases and the air, evaporation and condensation of the operating fluid are achieved [11].

Steam air heaters are recuperative heat exchangers where heat from the water steam is continuously transferred to the air through a heating surface (tube walls). The metal parts of these air heaters are stationary, and heat is transferred by three heat-transfer mechanisms: two convection mechanisms and one conduction mechanism. The most used recuperative air heaters are the tubular type. In some cases, plate type air heaters can be used if the air and steam pressures are low [12,13].

In steam generators with $\mathrm{NO}_{\mathrm{x}}$ emission limitations, air heaters are usually not used. Air heaters require an increase in the combustion temperature, which simultaneously increases the $\mathrm{NO}_{\mathrm{x}}$ levels [14].

The scientific literature has largely concentrated on the usage of renewable energy sources. This is the field where solar air heaters were developed and investigated. Many scientists are analyzing solar air heaters, based on their performance and upgrades, in order to increase their efficiency [15-18]. A detailed review of current solar air heaters, their design configurations, methods of improvement, and applications, was presented by Kabeel et al. [19]. Although many scientific papers addressed land-based solar air heaters, this analysis focuses on marine steam air heaters that are working in a dynamic environment onboard ships. Marine air heaters work in two different regimes: with superheated steam from the system, or with steam from main turbine subtraction (the bleed steam system). The aim of this paper was to analyze which operating mode steam air heater is more energy- and exergy-efficient, and to propose a possible solution for improvement.

In this paper, a tubular recuperative marine steam air heater is analyzed. The heater was mounted on marine steam generator on a conventional liquefied natural gas (LNG) carrier. The operating parameters of all necessary fluid streams (pressures, temperatures, and mass flows) were measured in order to obtain specific enthalpies and specific entropies of each stream. The measurements provided for 25 different operation points during the main propulsion propeller speed increased. The obtained data were used for calculation of energy and exergy efficiencies and losses in each observed operating point. Using this method, the operating characteristics of the steam air heater, through different operating modes, were obtained. Finally, the influence of the ambient temperature on steam air heater exergy destruction and exergy efficiency was investigated. We found that increases in the ambient temperature increased the analyzed air heater exergy destruction, and reduced its exergy efficiency.

\section{Steam Air Heater Specifications and Operating Characteristics}

The steam air heater analyzed in this paper was a tubular, recuperative heat exchanger. According to producer specifications [20], the main steam air heater design data and operating characteristics are presented in Table 1.

The steam air heater cross-section and main overall dimensions is presented in Figure 1. Superheated steam from steam generator, or from main turbine subtraction, passes through heat exchanger tubes. At the heat exchanger inlet (left side of Figure 1), steam passes through several safety and control valves. Measuring equipment for steam temperature, pressure, and mass flow is mounted on heat exchanger connecting pipes, before and after heat exchanger body (steam and condensate measuring equipment). Air heater tubes are mounted under the slope of $7^{\circ}$, in relation to the horizontal plane, because superheated steam, which enters into the air heater, condensates after heat exchange. Condensation can occur anywhere in air heater tubes, so condensate will descend down the pipes by gravity. At the air heater outlet, all steam condenses and condensates (with still relatively high temperature) are conveyed to the low-pressure feed water heater. Convection and conduction are the main mechanisms for heat exchange from steam to air. Desired mass flow of air (from ship engine room through air heater) is achieved, with a forced draft fan mounted before the steam air heater. The operating characteristics and specifications of the forced draft fan are not analyzed in this study, 
but it was necessary to measure air operating parameters at the forced draft fan outlet (steam air heater inlet) to perform air heater analysis.

Table 1. Analyzed steam air heater design data.

\begin{tabular}{ccc}
\hline \multicolumn{3}{c}{ Air Heater Design Data } \\
\hline Surface area & $655 \mathrm{~m}^{2}$ & \\
Type & Fin tube & \\
Weight per shell & $3500 \mathrm{~kg}$ & \\
\hline & Air side & Steam side \\
\hline Kind of fluid & Air & Steam \\
Fluid quantity (Max./Design) & $79,062 / 58,324 \mathrm{~kg} / \mathrm{h}$ & $2992 / 2121 \mathrm{~kg} / \mathrm{h}$ \\
Pressure drop & $0.158 \mathrm{kPa}$ & $0.118 \mathrm{kPa}$ \\
Design pressure & $14.7 \mathrm{kPa}$ & $0.98 \mathrm{MPa}$ \\
Operating pressure & - & $0.59 \mathrm{MPa}$ \\
Hydro test & - & $1.47 \mathrm{MPa}$ \\
Design temperature & $150{ }^{\circ} \mathrm{C}$ & $350{ }^{\circ} \mathrm{C}$ \\
Operating temperature (Inlet/Outlet) & $38 / 120^{\circ} \mathrm{C}$ & $240 / 158.05{ }^{\circ} \mathrm{C}$ \\
Number of passes per shell & 1 & 1 \\
\hline
\end{tabular}

The air heater tube arrangement, along with tube dimensions, are presented in Figure 2, where embedded fins mounted on each tube are depicted in an enlarged view. Embedded fins are necessary in this type of heat exchanger for increasing the heat exchange area. Without fins, heat exchange will be insufficient, and the air heater efficiency will be unacceptably low.

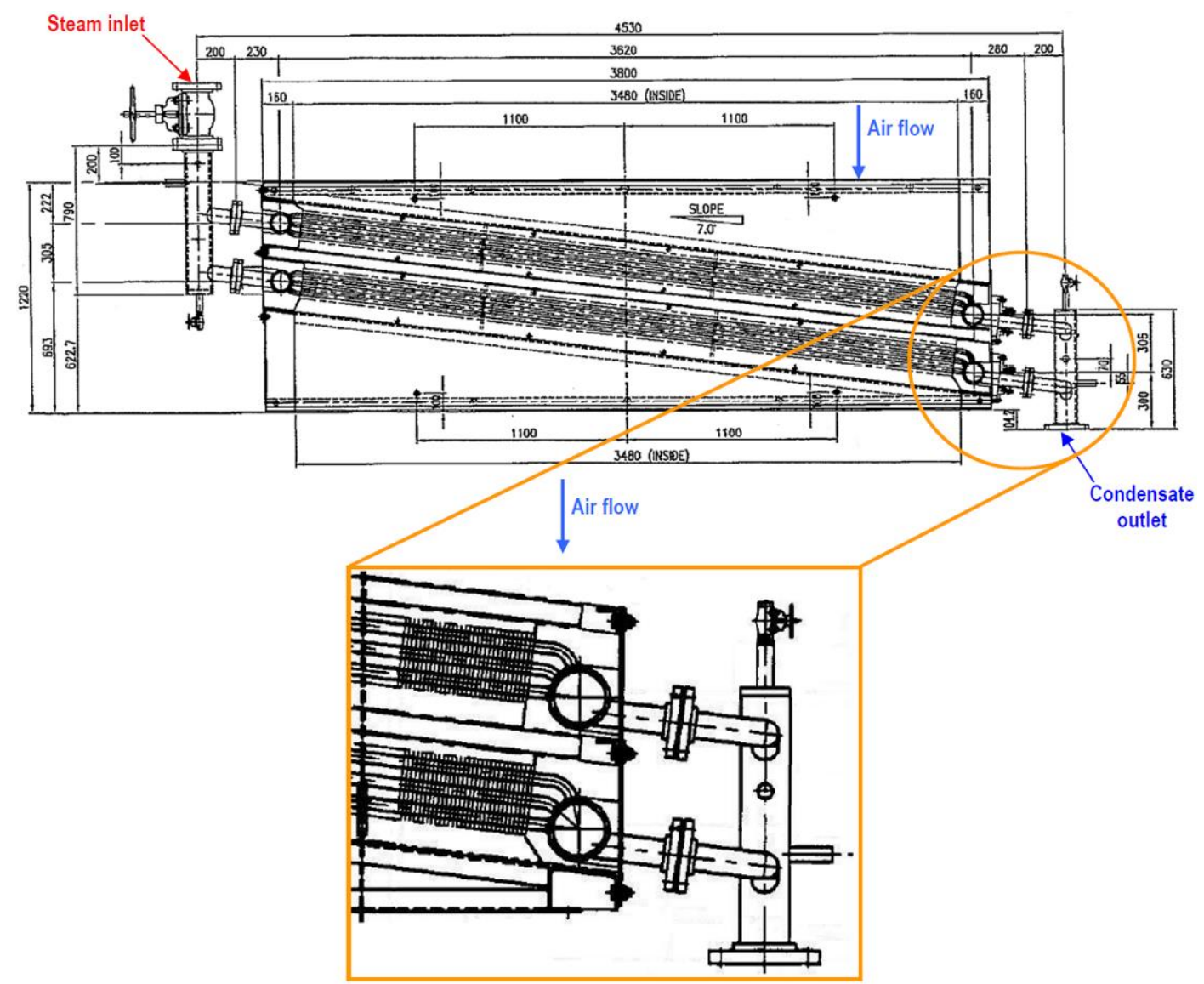

Figure 1. Cross-section of the analyzed steam air heater with main overall dimensions. 

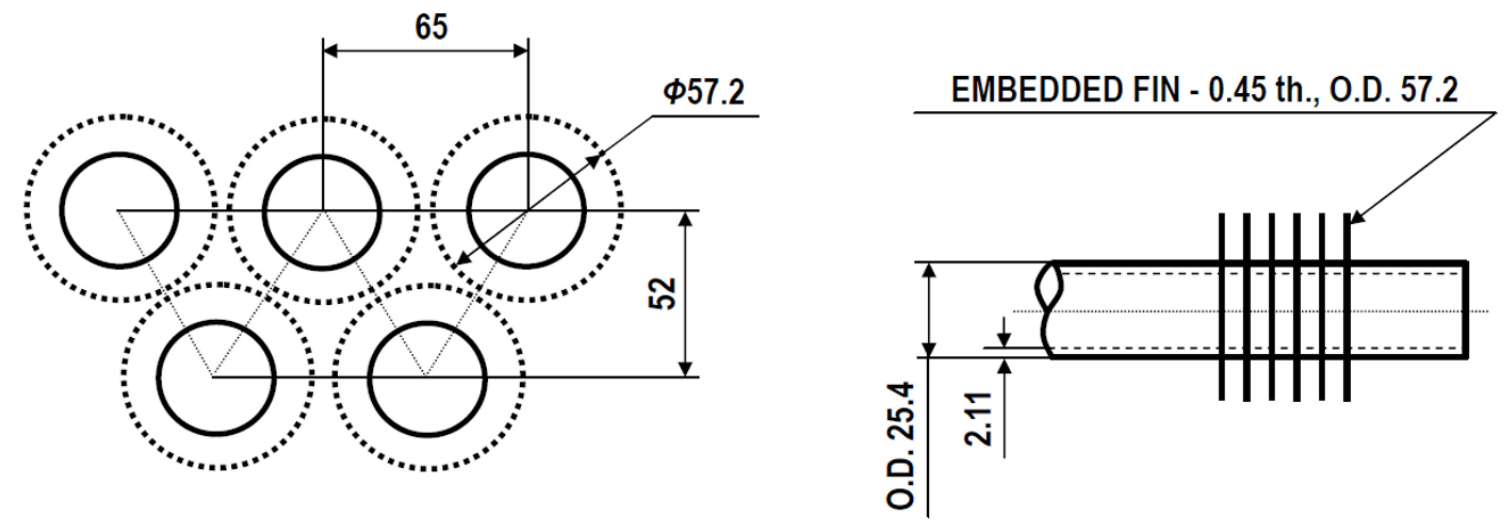

Figure 2. Steam air heater tube arrangement and tube detail.

The marine steam air heater was mounted on steam generator type MB-4E-KS [21,22]. The LNG carrier propulsion plant is equipped with two identical mirror-oriented steam generators. The analyzed air heater was mounted on the second steam generator according to ship internal classification. Essential parts of the observed marine steam generator included burners that can independently burn diesel fuel or heavy fuel oil (HFO, as well as a combination of fuels (diesel/gas or HFO/gas). Burners were mounted in the upper part of the furnace [23]. A schematic view of the steam air heater mounted on the steam generator is presented in Figure 3. In this figure, there are four visible points where measurements of stream flow operating parameters for air heater analysis were recorded. The mathematical description of a steam air heater is based on these four measured points.

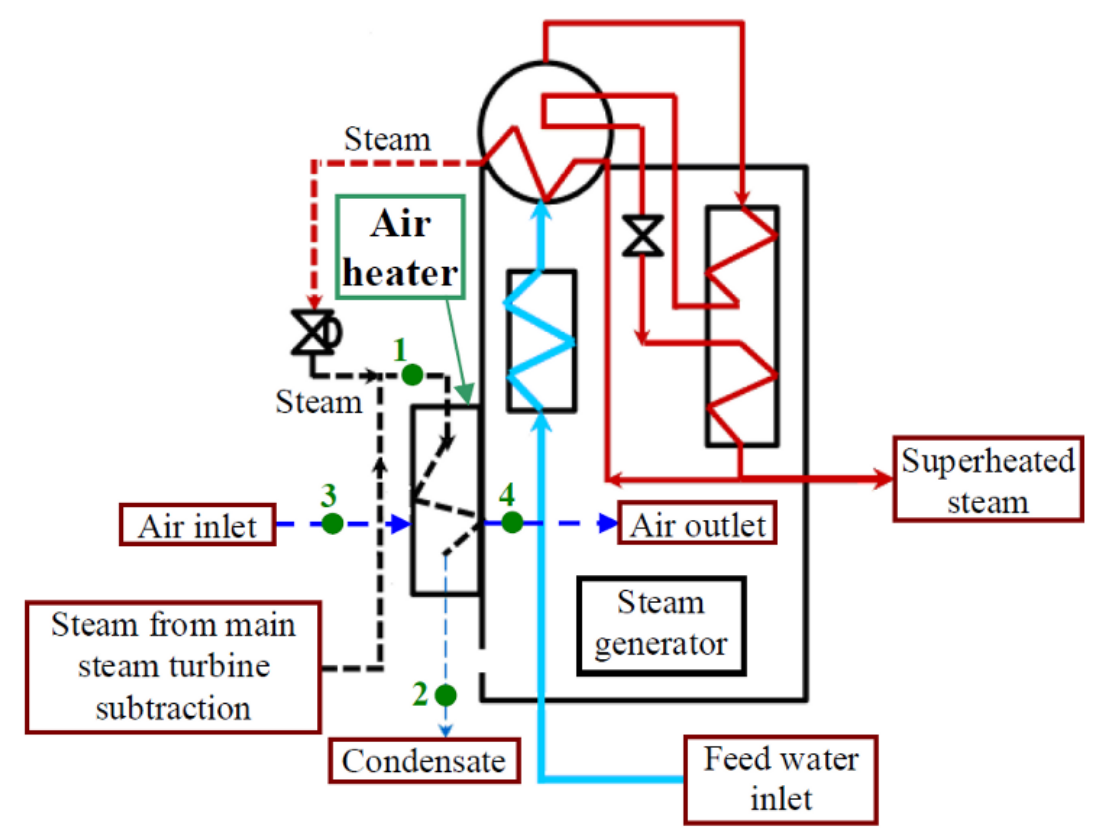

Figure 3. Schematic view of the steam air heater mounted on steam generator with main stream flows.

\section{Steam air Heater Numerical Description}

\subsection{Equations for the Energy and Exergy Analyses}

The first law of thermodynamics defines energy analysis. This analysis is related to energy conservation [24]. For a standard control volume in the steady state, along with disregarding potential and kinetic energy, the mass and energy balance equations are [25-27]

$$
\sum m_{I N}=\sum m_{\text {OUT }}
$$




$$
\dot{Q}-P=\sum m_{\text {OUT }} \cdot h_{\text {OUT }}-\sum m_{I N} \cdot h_{I N},
$$

where $m$ is mass rate, $Q$ is heat transfer, $P$ is power, and $h$ is specific enthalpy.

The energy of a flow for any fluid stream is calculated using the equation

$$
\dot{E}=\dot{m} \cdot h
$$

The type of the analyzed system or control volume defines energy efficiency. In most cases, energy efficiency can be defined as [28]

$$
\eta_{\text {en }}=\frac{\text { Energy output }}{\text { Energy input }}
$$

The second law of thermodynamics defines exergy and exergy analysis [29]. A standard volume in the steady state is represented by the following main exergy balance equation [30-33]:

$$
\dot{X}_{\text {heat }}-P=\sum m_{\text {OUT }} \cdot \varepsilon_{\text {OUT }}-\sum m_{I N} \cdot \varepsilon_{I N}+E_{\text {ex,D }} .
$$

From Equation (5), the net exergy transfer by heat $\left(\dot{X}_{\text {heat }}\right)$ at temperature $T$ is equal to [34]

$$
\dot{X}_{\text {heat }}=\sum\left(1-\frac{T_{0}}{T}\right) \cdot \dot{Q}
$$

In the literature $[35,36]$, a definition of specific exergy can be found:

$$
\varepsilon=\left(h-h_{0}\right)-T_{0} \cdot\left(s-s_{0}\right) .
$$

The exergy of a flow for any fluid stream is calculated according to Taner et al. [37] and Mrzljak et al. [38] by using

$$
\dot{E}_{e x}=\dot{m} \cdot \varepsilon=\dot{m} \cdot\left[\left(h-h_{0}\right)-T_{0} \cdot\left(s-s_{0}\right)\right] .
$$

The exergy efficiency of a control volume is also called second law efficiency or effectiveness [39]. The overall definition of exergy efficiency is

$$
\eta_{\text {ex }}=\frac{\text { Exergy output }}{\text { Exergy input }}
$$

The above equations, along with energy and exergy balances, were used for steam air heater analysis.

\subsection{Energy and Exergy Analysis of Steam Air Heater from Marine Steam Generator}

For the steam air heater analyzed in this study, all required operating points are presented in Figure 3. From the measured pressures and temperatures for each fluid stream, specific enthalpies and entropies were calculated using NIST REFPROP 8.0 software [40]. Mass and energy and exergy balances for the analyzed steam air heater are presented below.

Mass balance is

$$
\begin{aligned}
& \dot{m}_{1}=\dot{m}_{2}, \\
& \dot{m}_{3}=\dot{m}_{4} .
\end{aligned}
$$

For energy balance [41], the energy power input is calculated as

$$
\dot{E}_{\text {en,IN }}=m_{1} \cdot h_{1}-m_{2} \cdot h_{2}=m_{1} \cdot\left(h_{1}-h_{2}\right) .
$$


Energy power output is calculated as

$$
\dot{E}_{\text {en }, \text { OUT }}=m_{4} \cdot h_{4}-m_{3} \cdot h_{3}=m_{3} \cdot\left(h_{4}-h_{3}\right) .
$$

Energy power loss is calculated as

$$
\dot{E}_{e n, P L}=\dot{E}_{e n, I N}-\dot{E}_{e n, \text { OUT }}=m_{1} \cdot h_{1}-m_{2} \cdot h_{2}-m_{4} \cdot h_{4}+m_{3} \cdot h_{3},
$$

and energy efficiency [42] is calculated as

$$
\eta_{e n}=\frac{\dot{E}_{e n, \mathrm{OUT}}}{\dot{E}_{e n, I N}}=\frac{m_{4} \cdot h_{4}-m_{3} \cdot h_{3}}{m_{1} \cdot h_{1}-m_{2} \cdot h_{2}} .
$$

For exergy balance [43], the exergy power input is

$$
\dot{E}_{e x, I N}=m_{1} \cdot \varepsilon_{1}-m_{2} \cdot \varepsilon_{2}=m_{1} \cdot\left(\varepsilon_{1}-\varepsilon_{2}\right),
$$

the exergy power output is

$$
\dot{\mathrm{E}}_{e x, \mathrm{OUT}}=m_{4} \cdot \varepsilon_{4}-m_{3} \cdot \varepsilon_{3}=m_{3} \cdot\left(\varepsilon_{4}-\varepsilon_{3}\right),
$$

the exergy power loss (exergy destruction)

$$
\dot{E}_{e x, D}=\dot{E}_{e x, I N}-\dot{E}_{e x, \text { OUT }}=m_{1} \cdot \varepsilon_{1}-m_{2} \cdot \varepsilon_{2}-m_{4} \cdot \varepsilon_{4}+m_{3} \cdot \varepsilon_{3},
$$

and the exergy efficiency [44] is calculated as

$$
\eta_{e n}=\frac{\dot{E}_{e x, \text { OUT }}}{\dot{E}_{e x, I N}}=\frac{m_{4} \cdot \varepsilon_{4}-m_{3} \cdot \varepsilon_{3}}{m_{1} \cdot \varepsilon_{1}-m_{2} \cdot \varepsilon_{2}} .
$$

The ambient state was selected as previously proposed [1,30]: pressure, $p_{0}=0.1 \mathrm{MPa}=1 \mathrm{bar}$; and temperature, $T_{0}=25^{\circ} \mathrm{C}=298.15 \mathrm{~K}$.

\section{Steam Air Heater Stream Flows: Measuring Equipment and Measurement Results}

The measurement results of the required operating parameters (pressure, temperature, and mass flow) for each steam air heater operating fluid are presented in Table 2, in relation to the main propulsion propeller speed. The main propulsion propeller speed is directly proportional to the steam generator-and, therefore, the steam air heater-load. Measurement results were obtained from the existing measuring equipment mounted in four measured places, presented in Figure 3. Specifications of used measuring equipment are presented in the Appendix $A$ at the end of the paper.

Measured pressures and temperatures were used for air-specific enthalpy and entropy calculations. The NIST REFPROP software has several possibilities for calculating air properties; in this study, air as a mixture of nitrogen, oxygen, and argon was selected. The main properties of the selected air are presented in Table 3. 
Table 2. Measurement results for steam, condensate, and air stream flows during various air heater operation regimes.

\begin{tabular}{|c|c|c|c|c|c|c|c|c|c|c|c|c|}
\hline \multirow[b]{2}{*}{ 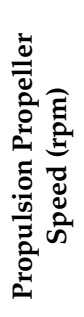 } & \multicolumn{3}{|c|}{$\begin{array}{c}\text { Steam at the Air Heater } \\
\text { Inlet }\left(1^{*}\right)\end{array}$} & \multicolumn{3}{|c|}{$\begin{array}{l}\text { Condensate at the Air } \\
\text { Heater Outlet }\left(2^{*}\right)\end{array}$} & \multicolumn{3}{|c|}{$\begin{array}{l}\text { Air at the Air Heater } \\
\text { Inlet }\left(3^{*}\right)\end{array}$} & \multicolumn{3}{|c|}{$\begin{array}{c}\text { Air at the Air Heater } \\
\text { Outlet }\left(4^{*}\right)\end{array}$} \\
\hline &  & 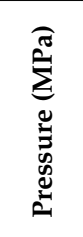 & 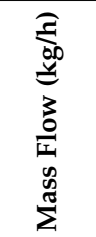 & 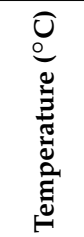 &  & 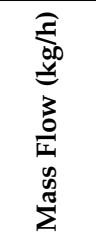 & 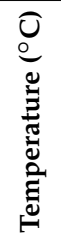 & 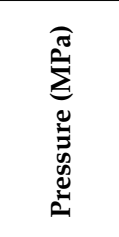 & 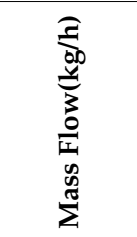 & 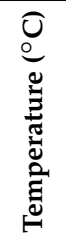 & 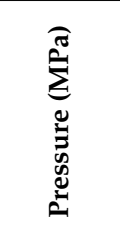 &  \\
\hline 0.00 & 188.40 & 0.550 & 789.5 & 155.4 & 0.550 & 789.5 & 55 & 0.10051 & $17,277.75$ & 153 & 0.10036 & $17,277.75$ \\
\hline 25.58 & 236.20 & 0.549 & 1676.0 & 155.3 & 0.549 & 1676.0 & 45 & 0.10154 & $40,466.88$ & 138 & 0.10139 & $40,466.88$ \\
\hline 34.33 & 228.53 & 0.550 & 1646.0 & 148.0 & 0.452 & 1646.0 & 44 & 0.10155 & $40,037.02$ & 137 & 0.10142 & $40,037.02$ \\
\hline 41.78 & 219.66 & 0.550 & 1696.0 & 155.4 & 0.550 & 1696.0 & 45 & 0.10149 & $39,920.58$ & 139 & 0.10137 & $39,920.58$ \\
\hline 53.50 & 208.40 & 0.549 & 1762.0 & 155.3 & 0.549 & 1762.0 & 50 & 0.10228 & $45,879.12$ & 134 & 0.10215 & $5,879.12$ \\
\hline 56.65 & 211.06 & 0.549 & 1854.0 & 155.3 & 0.549 & 1854.0 & 44 & 0.10 & 44,20 & 136 & 0.10097 & $44,208.90$ \\
\hline 61.45 & 211.03 & 0.548 & 2046.5 & 155.3 & 0.548 & 2046.5 & 42 & 0.10 & 50,39 & 131 & 0.10141 & $50,399.64$ \\
\hline 62.52 & 214.33 & 0.551 & 2011.0 & 155.5 & 0.551 & 2011.0 & 44 & 0.10144 & $50,266.98$ & 132 & 0.10132 & $50,266.98$ \\
\hline 63.55 & 212.58 & 0.548 & 2075.0 & 155.3 & 0.548 & 2075.0 & 41 & 0.10165 & $51,811.38$ & 129 & 0.10151 & $51,811.38$ \\
\hline 65.10 & 211.29 & 0.547 & 2103.5 & 155.2 & 0.547 & 2103.5 & 41 & 0.10177 & $53,086.68$ & 128 & 0.10165 & $53,086.68$ \\
\hline 66.08 & 214.13 & 0.546 & 2153.0 & 155.1 & 0.546 & 2153.0 & 41 & 0.10187 & $54,501.66$ & 128 & 0.10176 & $54,501.66$ \\
\hline \multirow[b]{2}{*}{ 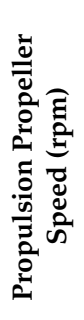 } & \multicolumn{3}{|c|}{$\begin{array}{c}\text { Steam at the Air Heater } \\
\text { Inlet }\left(1^{*}\right)\end{array}$} & \multicolumn{3}{|c|}{$\begin{array}{l}\text { Condensate at the Air } \\
\text { Heater Outlet }\left(2^{*}\right)\end{array}$} & \multicolumn{3}{|c|}{$\begin{array}{l}\text { Air at the Air Heater } \\
\text { Inlet }\left(3^{*}\right)\end{array}$} & \multicolumn{3}{|c|}{$\begin{array}{c}\text { Air at the Air Heater } \\
\text { Outlet }\left(4^{*}\right)\end{array}$} \\
\hline &  & 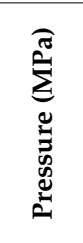 & 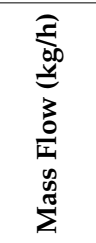 & 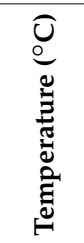 & 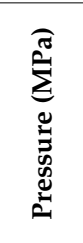 &  & 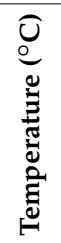 & 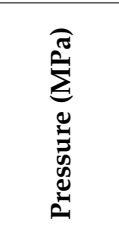 & 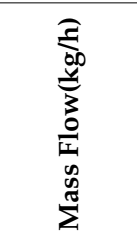 &  & 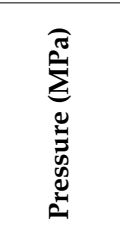 & 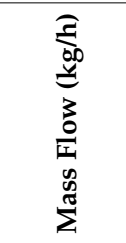 \\
\hline 67.68 & 215.86 & 0 & 34.0 & 155.1 & & U & 41 & & & 127 & 0 & 4 \\
\hline 68.66 & 217.41 & 0.548 & 2210.5 & 155.3 & 0.548 & 2210.5 & 41 & 0.10214 & $57,363.30$ & 126 & 0.10203 & $57,363.30$ \\
\hline 69.49 & 217.43 & 0.549 & 2225.0 & 155.3 & 0.549 & 2225.0 & 41 & 0.10218 & $58,474.62$ & 125 & 0.10206 & $58,474.62$ \\
\hline 70.37 & 217.54 & 0.550 & 2235.0 & 155.4 & 0.550 & 2235.0 & 41 & 0.10222 & $58,754.70$ & 125 & 0.10209 & $58,754.70$ \\
\hline 71.03 & 217.28 & 0.551 & 2177.5 & 155.5 & 0.551 & 2177.5 & 42 & 0.10225 & $57,865.86$ & 125 & 0.10213 & $57,865.86$ \\
\hline 73.09 & 215.36 & 0.551 & 2238.5 & 155.5 & 0.551 & 2238.5 & 42 & 0.10258 & $60,840.72$ & 123 & 0.10247 & $60,840.72$ \\
\hline 74.59 & 212.53 & 0.550 & 2360.5 & 154.6 & 0.539 & 2360.5 & 42 & 0.10292 & $64,056.60$ & 123 & 0.10279 & $64,056.60$ \\
\hline 76.56 & 212.53 & 0.550 & 2423.0 & 154.1 & 0.531 & 2423.0 & 42 & 0.10345 & $67,504.14$ & 121 & 0.10333 & $67,504.14$ \\
\hline 78.41 & 212.11 & 0.550 & 2418.5 & 154.8 & 0.541 & 2418.5 & 42 & 0.10368 & $69,049.62$ & 119 & 0.10354 & $69,049.62$ \\
\hline 79.46 & 261.00 & 0.549 & 2362.0 & 155.3 & 0.549 & 2362.0 & 42 & 0.10406 & $71,468.28$ & 118 & 0.10394 & $71,468.28$ \\
\hline 80.44 & 256.00 & 0.580 & 2364.0 & 157.5 & 0.580 & 2364.0 & 42 & 0.10438 & $72,818.82$ & 116 & 0.10427 & $72,818.82$ \\
\hline 81.49 & 253.00 & 0.568 & 2321.5 & 156.6 & 0.568 & 2321.5 & 43 & 0.10429 & $72,399.96$ & 116 & 0.10416 & $72,399.96$ \\
\hline 82.88 & 250.00 & 0.590 & 2380.0 & 158.1 & 0.590 & 2380.0 & 42 & 0.10464 & $73,807.20$ & 114 & 0.10452 & $73,807.20$ \\
\hline 83.00 & 256.40 & 0.593 & 2346.0 & 158.3 & 0.593 & 2346.0 & 43 & 0.10469 & $74,167.02$ & 115 & 0.10457 & $74,167.02$ \\
\hline
\end{tabular}

Table 3. The main properties of air used in numerical analysis.

\begin{tabular}{ll}
\hline \multicolumn{2}{c}{ Air $\left(\mathbf{N}_{\mathbf{2}}+\mathbf{A r}+\mathbf{O}_{\mathbf{2}}\right)$} \\
\hline Molar mass: & $28.965 \mathrm{~kg} / \mathrm{kmol}$ \\
Triple point temperature: & $-213.4^{\circ} \mathrm{C}$ \\
Normal boiling point temperature: & $-194.25^{\circ} \mathrm{C}$ \\
Critical point temperature: & $-140.62{ }^{\circ} \mathrm{C}$ \\
Critical point pressure: & $3.786 \mathrm{MPa}$ \\
Critical point density: & $342.68 \mathrm{~kg} / \mathrm{m}^{3}$ \\
Acentric factor: & 0.0335 \\
\hline
\end{tabular}

\section{Results and Discussion}

The temperature changes in steam, condensate, and air at the steam air heater inlet and outlet are presented in Figure 4. The temperature of the steam at the steam air heater inlet firstly increases during 
steam system startup at lower propulsion propeller speeds. After the increase, steam temperature stabilizes at approximately $210-215^{\circ} \mathrm{C}$. At a main propulsion propeller speed of $79.46 \mathrm{rpm}$, an increase in steam inlet temperature was noticeable. That measured point represents the moment at which steam is led to the air heater from steam turbine subtraction, and not from the steam generator, as before. When the pressure for the steam reducing station from steam generators is less than the pressure from the steam turbine subtraction, the steam reducing station closes, and steam from the main turbine is led to the steam air heater. At the highest measured steam system loads, the other steam system components have greater needs for superheated steam (main steam turbine, turbo-generators, and low-power steam turbine for the main feed water pump drive), so, during that operation regime, the steam generator cannot produce enough steam for the air heater. A compromise solution during the highest steam system loads involves bringing superheated steam to the air heater from the steam turbine subtraction. Steam from the steam turbine subtraction is hotter and at a slightly higher pressure than the steam from the steam generator.

The temperature of the condensate at the air heater outlet is approximately constant during the whole steam system loads. Condensate temperature was around $155^{\circ} \mathrm{C}$, and increased very slightly at the highest system loads where the heating steam leads to the air heater from the steam turbine.

During the entire observation of steam system loads, the temperature of the air at the air heater outlet constantly decreased. The reason for this decrease is a constant increase in air mass flow through the air heater (Table 2). Under the highest steam system loads, when superheated steam has a higher temperature and pressure, it was unable to maintain air temperature at least at constant values. Air mass flow through the air heater must constantly increase because the steam generator produces higher amounts of superheated steam as the system load increases; therefore, more fuel is burnt in the steam generator combustion chamber.

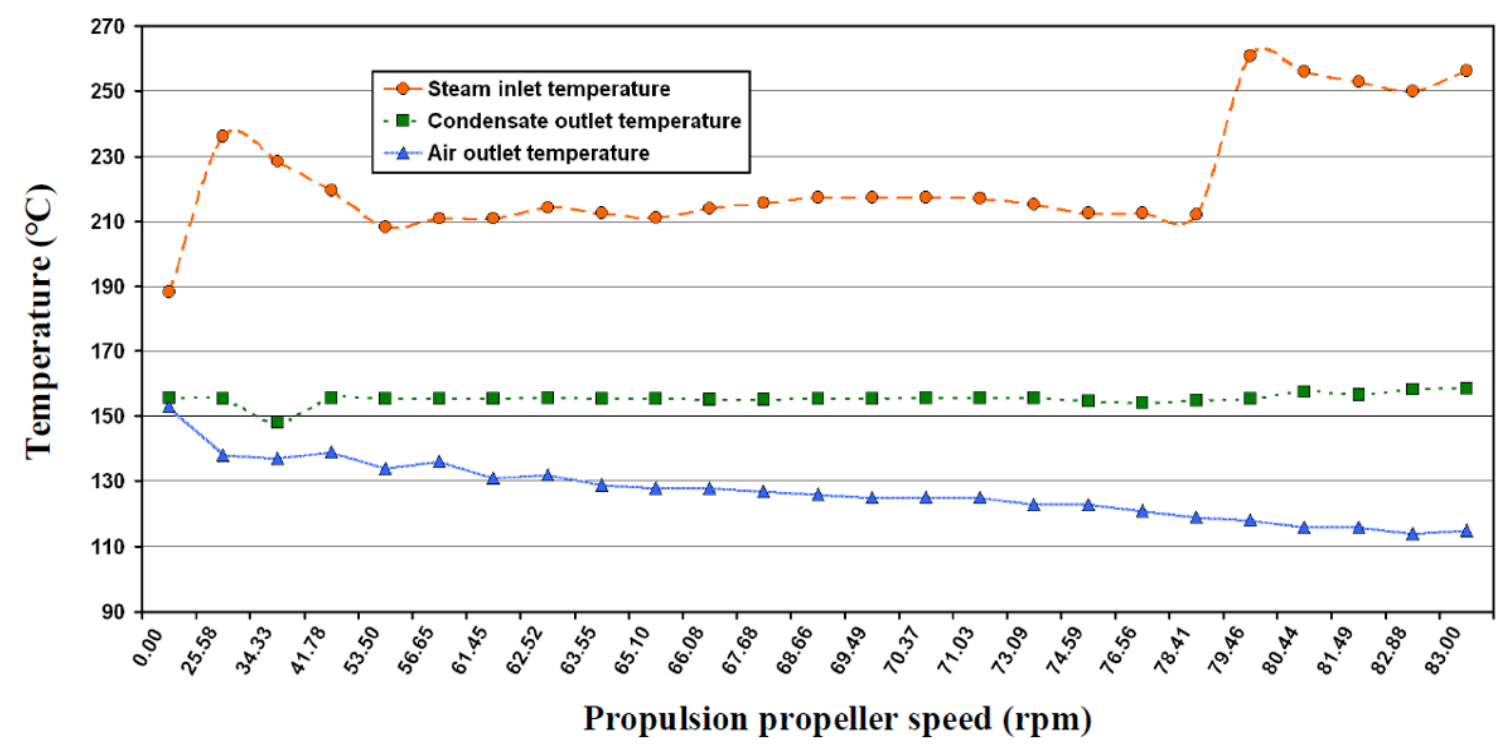

Figure 4. Temperature change of three operating substances through steam air heater.

Steam air heater energy power input and output are presented in Figure 5 for all observed steam system loads. From the lowest to the highest steam system loads, the air heater energy power input and output increased almost constantly with the exception of some individual operating points. From the energy aspect, the steam air heater has the same operating principle as the other steam system components-energy power input and output are higher with higher loads. The energy power input was $476.4 \mathrm{~kW}$ at the lowest loads and increased to around $1500 \mathrm{~kW}$ at the highest system load, whereas, at the same observed operating range, the energy power output ranged from $475.9 \mathrm{~kW}$ to approximately $1496 \mathrm{~kW}$. 
The difference between energy power input and output is small. From this trend, low energy power losses and, therefore, very high energy efficiencies were expected of the analyzed steam air heater for all observed loads. Energy analysis of the air heater, which did not consider the ambient parameters, led us to conclude that the air heater is one of the best-balanced components in the entire steam system.

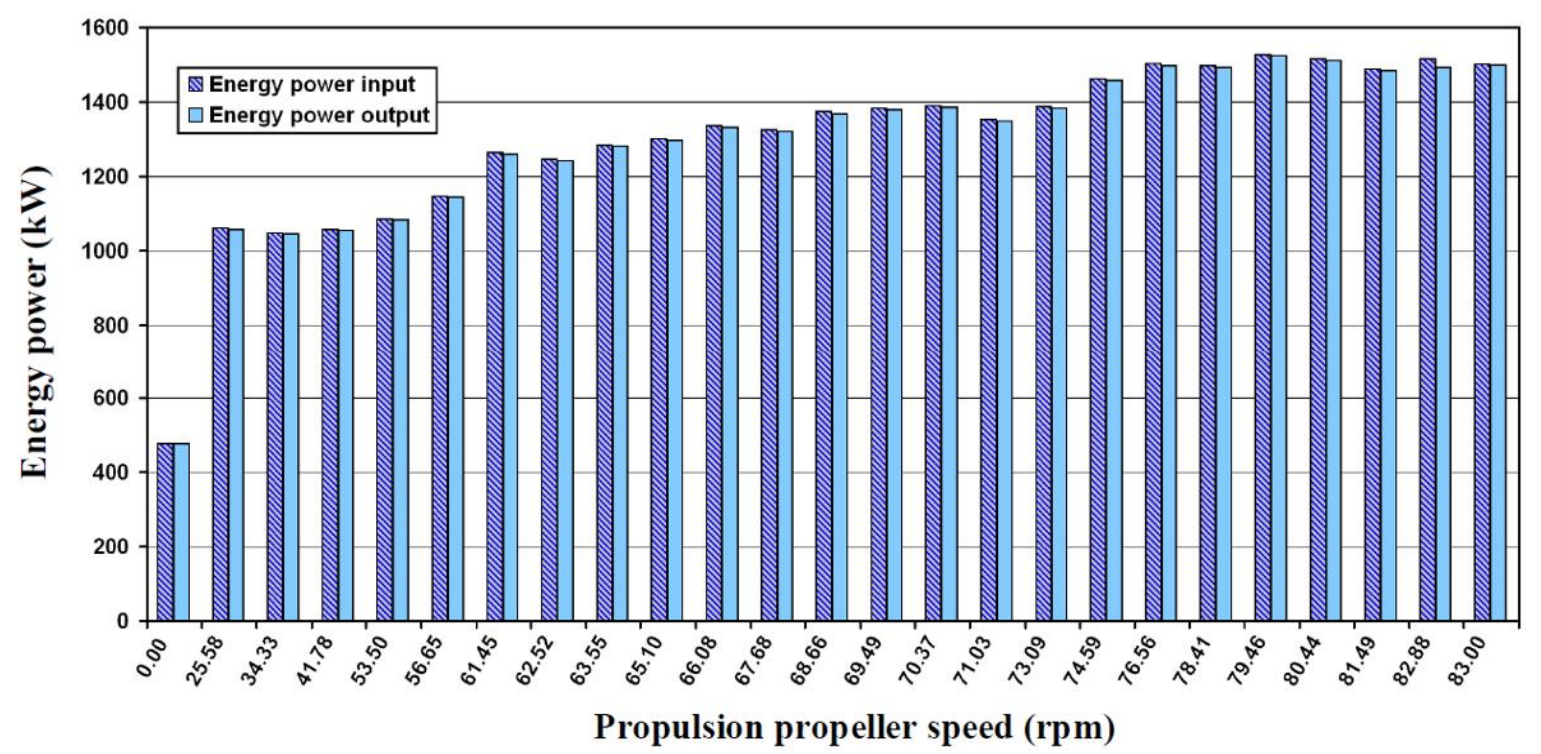

Figure 5. Steam air heater energy power input and output for various loads.

The change in exergy power input and output of the air heater showed a trend similar to the energy power input and output, as shown in Figure 6. Exergy power input and output increased with increasing system load. The steam air heater exergy power input ranged from $145.4 \mathrm{~kW}$ to around $470 \mathrm{~kW}$, whereas exergy power output varied between $97.6 \mathrm{~kW}$ and around $225 \mathrm{~kW}$ from the lowest to the highest observed steam system load, respectively. As seen in Figure 6, the difference in the exergy power input and output of the steam air heater, which represents exergy destruction, was not as low as the difference in the energy power input and output (Figure 5).

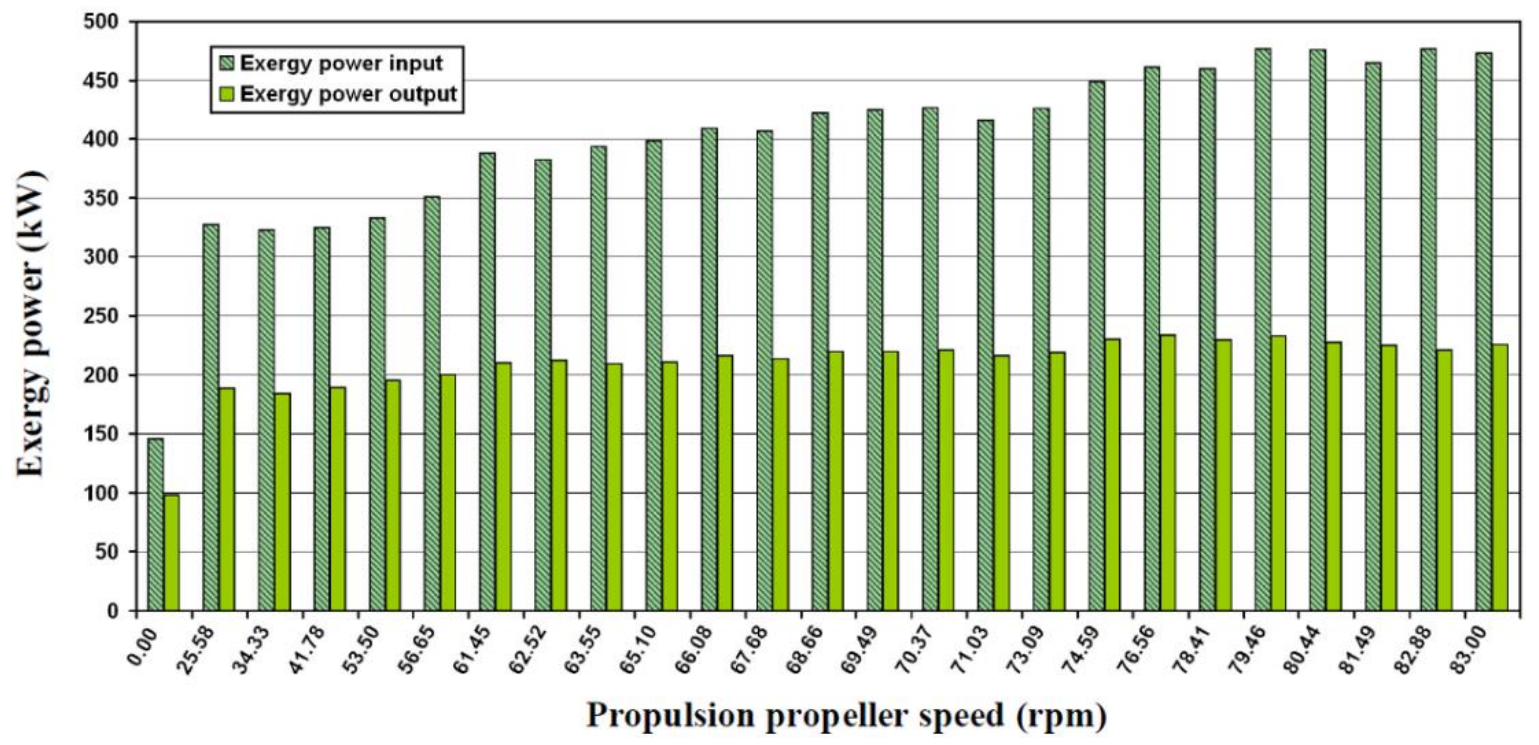

Figure 6. Steam air heater exergy power input and output for various loads. 
Our exergy analysis of any control volume (in this case, the steam air heater) considered the ambient pressure and temperature in which the component operates. By accounting for the ambient parameters, the steam air heater was not as well balanced a component as the energy analysis predicted. Due to the differences between the steam air heater exergy power input and output in all observed system loads, we expected high exergy power losses (high exergy destruction) and, therefore, low exergy efficiency. Also, the differences in air heater exergy power input and output increased as steam system load increased.

Energy power losses and the energy efficiency of the steam air heater during the observed steam system loads are presented in Figure 7. Energy power losses were small-between $0.5 \mathrm{~kW}$ and $5.5 \mathrm{~kW}$ at all observed operating points-with an exception of the operating point at the main propulsion propeller speed of $82.88 \mathrm{rpm}$ (energy power loss at that operating point was $24.1 \mathrm{~kW}$ ), which will be explained in detail. Due to small energy power losses, the energy efficiency of the steam air heater was between $99.63 \%$ and $99.90 \%$ for all observed operating points, again, with the exception of the operating point at $82.88 \mathrm{rpm}$, where energy efficiency decreased $98.41 \%$ due to increased energy power losses.

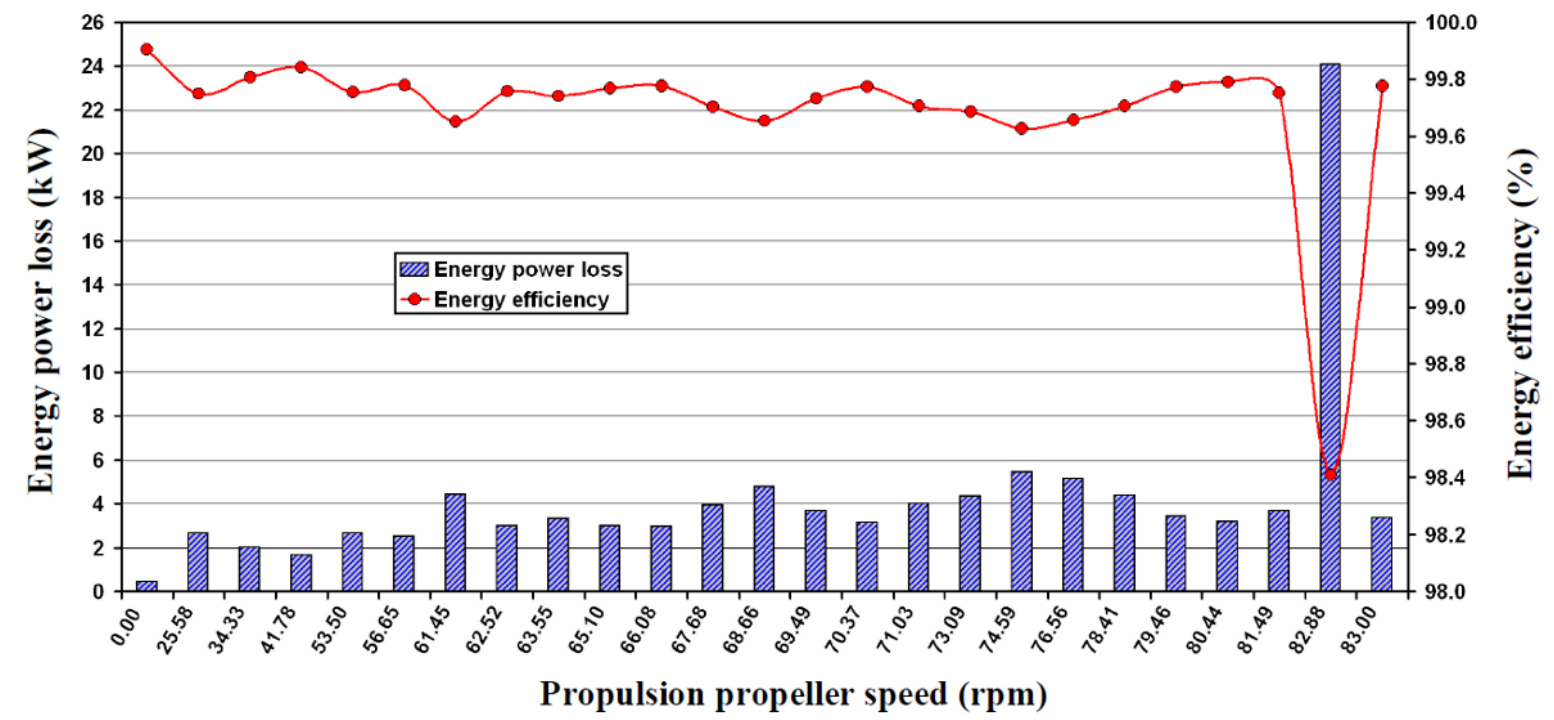

Figure 7. Energy power loss and energy efficiency of steam air heater under various loads.

To properly describe the air heater energy power loss and the decrease in energy efficiency at the operating point at the main propulsion propeller speed of $82.88 \mathrm{rpm}$, data from Table 2 and Equations (12)-(15) should be used. Energy power losses and efficiency were compared with observed operating points before and after $82.88 \mathrm{rpm}$ (operating points at $81.49 \mathrm{rpm}$ and $83.00 \mathrm{rpm}$ of the main propulsion propeller).

At the operating point of $81.49 \mathrm{rpm}$, the energy power input (related to steam) was $1485.9 \mathrm{~kW}$, whereas the energy power output (related to air) was $1482.2 \mathrm{~kW}$.

From $81.49 \mathrm{rpm}$ to $82.88 \mathrm{rpm}$, the steam temperature decreased $3{ }^{\circ} \mathrm{C}$, whereas the condensate temperature increased $1.5{ }^{\circ} \mathrm{C}$. At the same time, the steam mass flow increased at $58.5 \mathrm{~kg} / \mathrm{h}$. The difference in enthalpies of the steam and condensate decreased at the operating point at $82.88 \mathrm{rpm}$ in comparison with $81.49 \mathrm{rpm}$, but the increased steam mass flow caused an increase in energy power input (energy power input for $82.88 \mathrm{rpm}$ was $1514.4 \mathrm{~kW}$ ). When comparing air operating parameters between these two points, the air temperature at the air heater inlet decreased $1{ }^{\circ} \mathrm{C}$, whereas, at the air heater outlet, the air temperature decreased $2{ }^{\circ} \mathrm{C}$. At the same time, the air mass flow increased from $72,399.96 \mathrm{~kg} / \mathrm{h}$ to $73,807.20 \mathrm{~kg} / \mathrm{h}$. The difference in air enthalpies between the air heater outlet and inlet was much lower than the difference in enthalpies of the steam and condensate, so the energy power output at the operating point of $82.88 \mathrm{rpm}$ was only $1490.3 \mathrm{~kW}$, regardless of increased air 
mass flow. Therefore, we concluded that the main reason for the increase in energy power loss and simultaneous decrease in energy efficiency for the operating point at $82.88 \mathrm{rpm}$ was due to the notable steam mass flow increase in comparison with earlier operating points.

The air heater steam mass flow decreased from $2380 \mathrm{~kg} / \mathrm{h}$ to $2346 \mathrm{~kg} / \mathrm{h}$ between the operating points of $82.88 \mathrm{rpm}$ and $83.00 \mathrm{rpm}$. This was the main reason that led to an energy power loss of only $3.4 \mathrm{~kW}$ and energy efficiency of $99.78 \%$ at the operating point at $83.00 \mathrm{rpm}$.

The analyzed steam air heater was a well-balanced component from an energy viewpoint, because its energy efficiency did not fall below $98.4 \%$, whereas the energy power loss did not exceed $25 \mathrm{~kW}$ at any observed operating point. The exergy destruction and exergy efficiency of the steam air heater during all observed steam system loads are presented in Figure 8. In comparison with the energy power losses, the exergy destruction of the air heater was much greater, from $48 \mathrm{~kW}$ to $255 \mathrm{~kW}$. The air heater exergy destruction increased almost constantly from the lowest to the highest main propulsion propeller speeds. Therefore, the air heater exergy destruction had the highest values at the highest loads, which was unexpected because steam systems are usually designed based on the principle that all of its components are most efficient under the highest loads. This principle is certainly valuable in base-loaded conventional steam plants but, in this analysis, this conclusion is not the same for some components in marine steam plants, such as the steam air heater.

The high exergy destruction of the air heater, at all observed operating points and loads, led to proportionally low exergy efficiencies. Air heater exergy efficiency was the highest during the steam system startup (in the period of main propulsion turbine heating), which was $67.14 \%$. As the steam system load increased, air heater exergy efficiency decreased, and reached the lowest value of $46.34 \%$ at the highest observed loads (82.88 rpm).

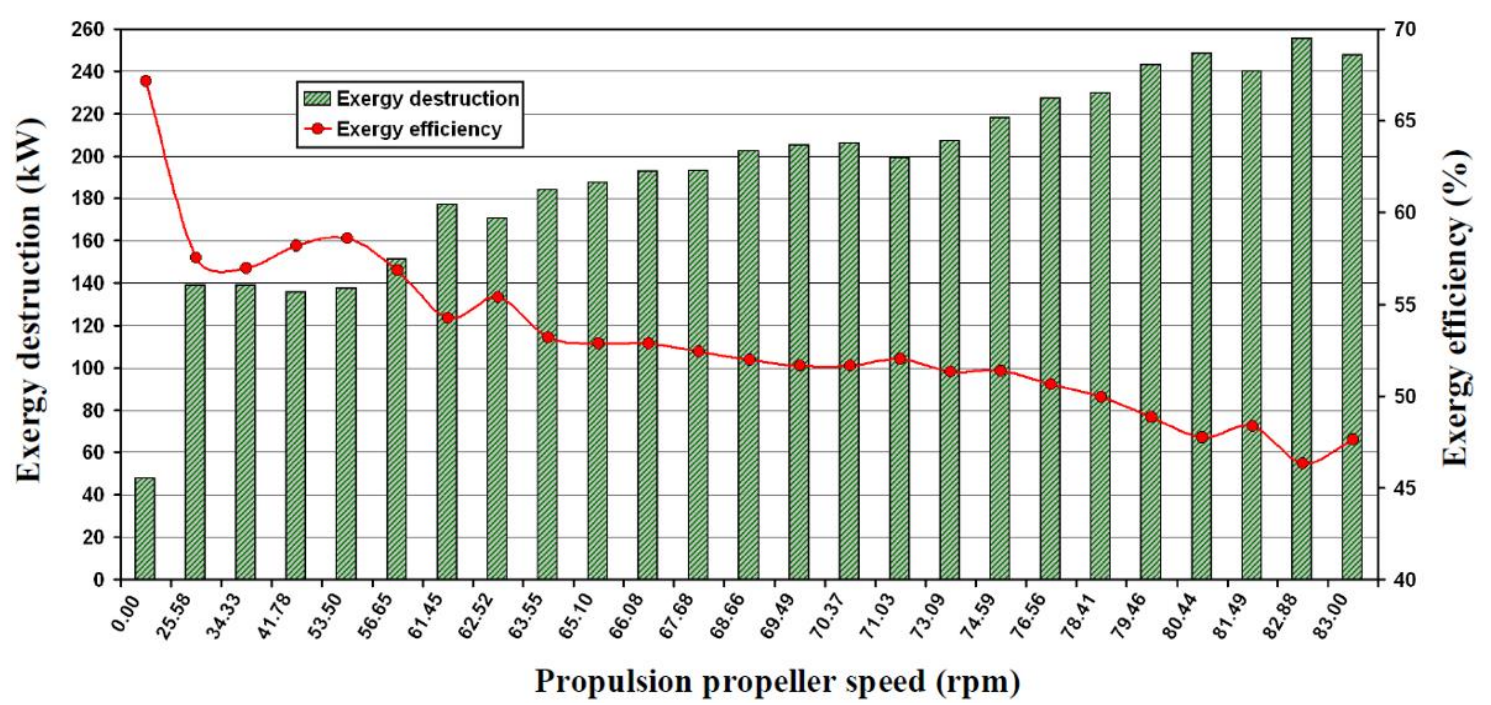

Figure 8. Exergy destruction and exergy efficiency of the steam air heater during various loads.

We had already concluded that the steam air heater is well-balanced from an energy viewpoint. Unfortunately, the same conclusion from the exergy analysis was not obtained. The steam air heater was not well-balanced when considering the ambient calculation parameters essential to exergy analysis. The main air heater problem, from the exergy viewpoint, is that the highest destruction and lowest exergy efficiency occurred at the highest observed loads. The highest loads in marine propulsion plants are commonly expected when operating the LNG carrier.

When analyzing any heat exchanger, the influence of the ambient temperature change on the exergy destruction and exergy efficiency should be examined. The ambient temperature and ambient pressure have no influence on the energy power loss or energy efficiency of any steam plant component. Variation in the ambient pressure has rarely been reported in the scientific or professional literature 
because the ambient pressure change minimally influences exergy destruction or efficiency for any observed component (volume).

Several authors reported the influence of the ambient temperature on exergy destruction and exergy efficiency for some industry processes [45] and, for some steam plant components. Ahmadi et al. [2], Aljundi [30], and Kopac et al. [46] declared that the change in the ambient temperature has little influence on steam plant components, with the exception of steam generators and condensers. For all of the observed steam plant components, exergy destruction increases, and exergy efficiency decreases during the increase in ambient temperature. The only exception is the steam condenser, whose exergy destruction decreases, and exergy efficiency increases during the increase in ambient temperature.

Ameri et al. [47] showed shown that a $10{ }^{\circ} \mathrm{C}$ change in the ambient temperature causes a $1 \%$ or less change in the exergy efficiency of high-power steam turbines. The same conclusion was obtained by Mrzljak et al. [38] for marine low-power steam turbines. The authors agreed that, for any steam turbine, with an increase in the ambient temperature, steam turbine exergy destruction increases, while its exergy efficiency decreases.

As presented in Figure 9, the analyzed steam air heater exergy destruction increased during increases in the ambient temperature, so the change in the exergy destruction of the steam air heater was the same as for all the other steam plant components with exception of the condenser. The ambient temperature varied from $10{ }^{\circ} \mathrm{C}$ to $40{ }^{\circ} \mathrm{C}$, which is the expected range of the ambient temperatures in the LNG carrier engine room. With a $10^{\circ} \mathrm{C}$ increase in the ambient temperature, steam air heater exergy destruction increased from $4.5 \mathrm{~kW}$ to $8 \mathrm{~kW}$, on average. The smallest increase in air heater exergy destruction occurred at lower loads, whereas the highest increase occurred at higher steam system loads. For example, at the lowest observed steam system load $(0.00 \mathrm{rpm})$, the steam air heater exergy destruction was $45.4 \mathrm{~kW}$ at an ambient temperature of $10^{\circ} \mathrm{C}$, whereas it was $50.2 \mathrm{~kW}$ at an ambient temperature of $40{ }^{\circ} \mathrm{C}$. At the highest steam system load $(83.00 \mathrm{rpm})$, the steam air heater exergy destruction was $235.6 \mathrm{~kW}$ at an ambient temperature of $10^{\circ} \mathrm{C}$, whereas it was $260.3 \mathrm{~kW}$ at an ambient temperature of $40^{\circ} \mathrm{C}$.

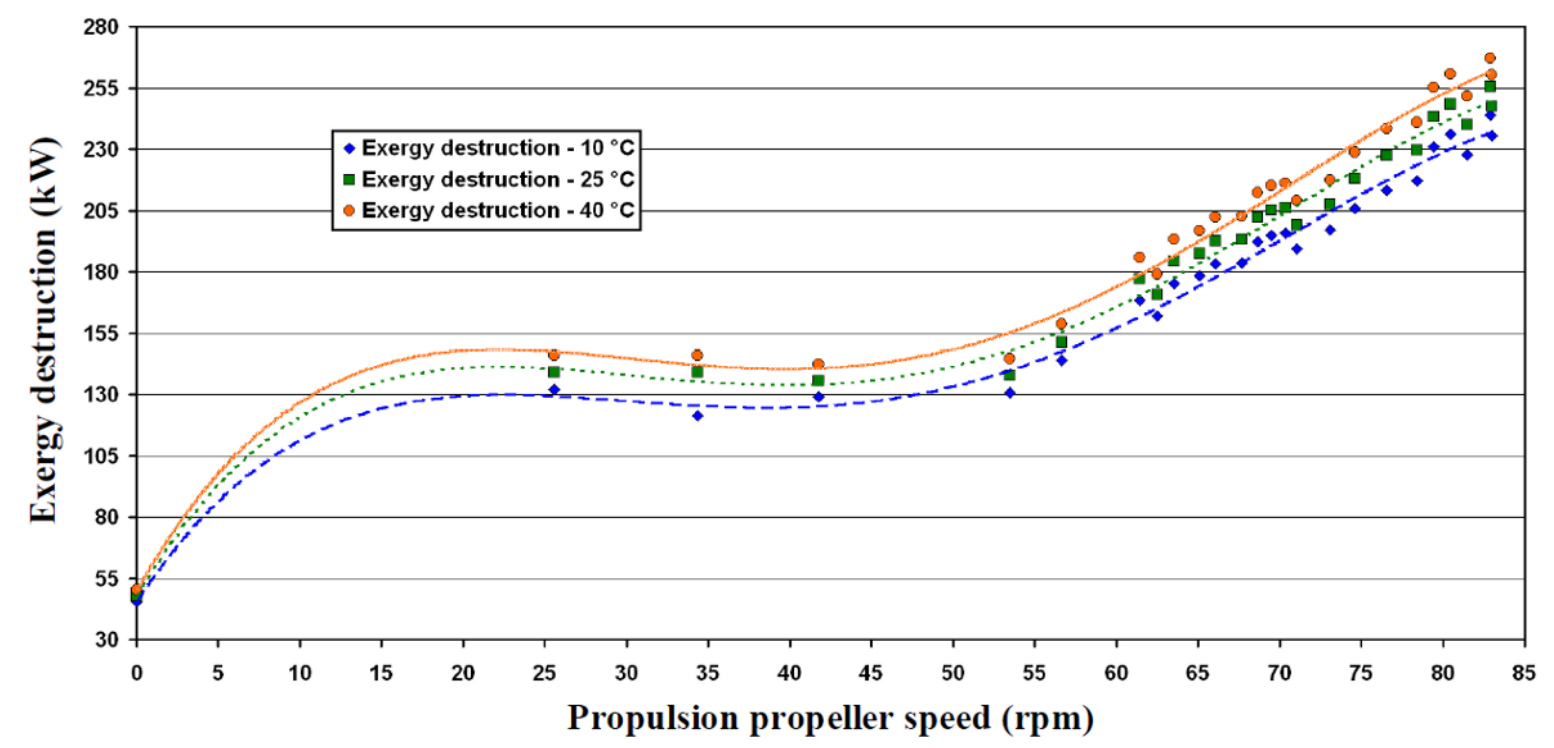

Figure 9. Steam air heater exergy destruction for the several ambient temperatures.

This change in steam air heater exergy destruction led us to conclude that the ambient temperature can significantly influence heater exergy efficiency.

Changes in the exergy efficiency of the steam air heater, during the change in the ambient temperature, are presented in Figure 10. In the case of exergy efficiency, the ambient temperature varied from $10^{\circ} \mathrm{C}$ to $40^{\circ} \mathrm{C}$. Like most of the other steam system components, the exergy efficiency of 
the steam air heater decreased as the ambient temperature increased. The trend in air heater exergy efficiency was the same, regardless of the observed ambient temperature. Exergy efficiency was the highest at the lowest loads, and constantly decreased during increases in steam system loads. The lowest exergy efficiencies of the steam air heater were achieved at the highest observed loads.

The highest exergy efficiency of the steam air heater was achieved at the ambient temperature of $10{ }^{\circ} \mathrm{C}$, which was $72 \%$ (0.00 rpm), after which it decreased to $55.1 \%$ (83.00 rpm). With a $10^{\circ} \mathrm{C}$ increase in the ambient temperature, the air heater exergy efficiency significantly decreased. In all observed operating points during the increase in ambient temperature, the average drop in air heater exergy efficiency was $4.5 \%$ from $10{ }^{\circ} \mathrm{C}$ to $20{ }^{\circ} \mathrm{C}, 5 \%$ from $20{ }^{\circ} \mathrm{C}$ to $30^{\circ} \mathrm{C}$, and $6 \%$ from $30{ }^{\circ} \mathrm{C}$ to $40{ }^{\circ} \mathrm{C}$.

The variance in the ambient temperature showed that the exergy efficiency of the analyzed steam air heater decreases during increases in ambient temperature. The percentage of exergy efficiency decrease is proportional to the ambient temperature increase. We concluded that the ambient temperature significantly impacts the steam air heater exergy efficiency change. So far, in the scientific literature, the authors did not find analyzed steam plant components or heat exchangers, in general, whose exergy efficiencies are significantly influenced by the ambient temperature.

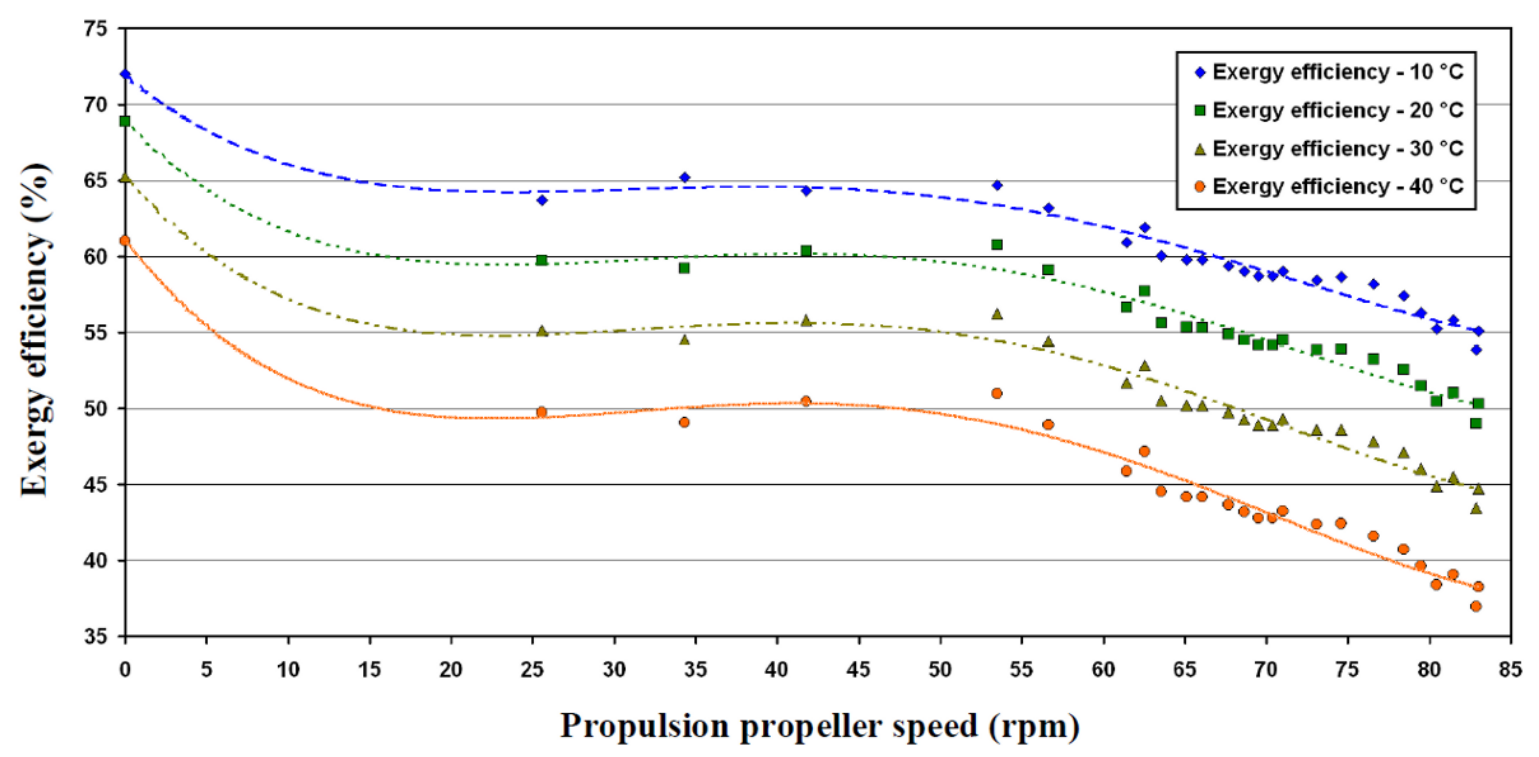

Figure 10. Steam air heater exergy efficiency for various ambient temperatures.

\section{Conclusions}

In this paper, we performed energy and exergy power losses and efficiency analysis of steam air heater mounted on a MB-4E-KS marine steam generator. Conventional air heaters from base-loaded conventional steam power plants use flue gases for air heating before air enters the steam generator. Flue gases from marine steam generators are not hot enough for air heating. Therefore, in the analyzed air heater, the heating medium was superheated steam. Steam enters the air heater from the steam generator or from main propulsion turbine subtraction. The air was taken from the ship engine room and accelerated using a marine forced draft fan.

Measurements of the air heater stream flows were recorded in a wide range of marine steam system loads, from system startup to the highest loads. At each measured operating point, we analyzed energy and exergy losses and efficiencies.

The temperature of the air after the steam air heater (at the steam generator entrance) constantly decreased from the lowest to the highest loads. The reason for this occurrence is because the mass flow of air constantly increases during increases in system loads, because the steam generator uses more fuel as load increases. Changing the superheated steam source does not influence the air temperature change at the steam generator inlet, regardless of higher temperature and pressure of steam subtracted from main turbine in comparison with steam from the steam generator. The analysis showed that 
steam air heater is under capacity at higher loads and that, at the highest steam system loads, when superheated steam has a higher temperature and pressure, the air temperature could not be maintained at the designed value of $120^{\circ} \mathrm{C}$. This occurred because the steam air heater only had two rows of heating elements. Although the benefit of two rows of heating elements is observable at the beginning (lower cost), at later stages, during ship use, fuel cost overtakes the initial advantages. Lower air temperatures increase fuel/natural gas consumption.

Steam air heater energy analysis showed that the analyzed air heater is a well-balanced device. Energy power inputs and outputs increase with increases in steam system loads. Energy power losses of the steam air heater were small—between $0.5 \mathrm{~kW}$ and $5.5 \mathrm{~kW}$ at all observed operating points—with the exception of only one operating point at which the energy power loss was $24.1 \mathrm{~kW}$. Small energy power losses in the air heater led to high energy efficiencies, which were between $99.63 \%$ and $99.90 \%$ at all observed operating points, except the one with the highest energy power losses. Even at operating points where energy power losses were $24.1 \mathrm{~kW}$, the air heater energy efficiency was more than appropriate at $98.41 \%$, which was the operating point at the main propulsion propeller speed of $82.88 \mathrm{rpm}$.

Exergy analysis of the steam air heater produced a totally different behavioral result in comparison with the energy analysis. Exergy destruction ranged from $48 \mathrm{~kW}$ to $255 \mathrm{~kW}$ for the entire observed range of steam system loads. In comparison with energy power losses, the exergy destruction of the air heater was larger by several orders of magnitude. The high exergy destruction led to exergy efficiencies much lower in comparison with energy efficiencies. The analyzed air heater exergy efficiencies decreased from $67.14 \%$ at the lowest to $46.34 \%$ at the highest steam system loads. From an exergy viewpoint, the steam air heater is not a well-balanced component, because its exergy destruction was the highest and exergy efficiency was the lowest at the highest system loads. The benefit of exergy analysis is that it provides better insight into the steam air heater operating conditions. If an extra row of heating elements is added, by maintaining a constant air temperature after the heater, boiler fuel consumption would be lowered, due to higher air enthalpy. Also, if the heating surface is increased by adding an extra heating element, the steam mass flow will be reduced, which will improve the exergy efficiency of the steam air heater.

Variations in the ambient temperature showed that the analyzed steam air heater behaves similarly to most other steam plant components, regardless of the steam plant type. Steam air heater exergy destruction increases, and exergy efficiency decreases, at higher ambient temperatures. In all observed steam air heater operating points under various steam system loads, a $10{ }^{\circ} \mathrm{C}$ increase in the ambient temperature caused an average drop in exergy efficiency in the range of $4.5 \%$ to $6 \%$. Decreases in steam air heater exergy efficiency are high as the ambient temperature increases. Therefore, we concluded that the ambient temperature significantly impacts the analyzed steam air heater exergy destruction and exergy efficiency. The presented steam air heater is a rare heat exchanger where exergy efficiency change is considerably influenced by the ambient temperature.

This analysis could be useful for a broad audience and, especially, for ship owners and steam air heater producers.

Author Contributions: Conceptualization, J.O., V.M. and I.P.; Data curation, V.M. and I.P.; Formal analysis, J.O., V.M. and I.P.; Investigation, V.M. and I.P.; Methodology, V.M.; Supervision, J.O. and V.M.; Validation, J.O. and V.M.; Writing-original draft, V.M.; Writing-review \& editing, J.O., V.M. and I.P.

Funding: This research received no external funding.

Acknowledgments: The authors would like to extend their appreciations to the main ship-owner office for conceding measuring equipment and for all help during the exploitation measurements. This work was supported by the University of Rijeka (contract No. 13.09.1.1.05) and Croatian Science Foundation-project DEcision Support System for green and safe ship RouTing.

Conflicts of Interest: The authors declare no conflict of interest. 


\section{Nomenclature}

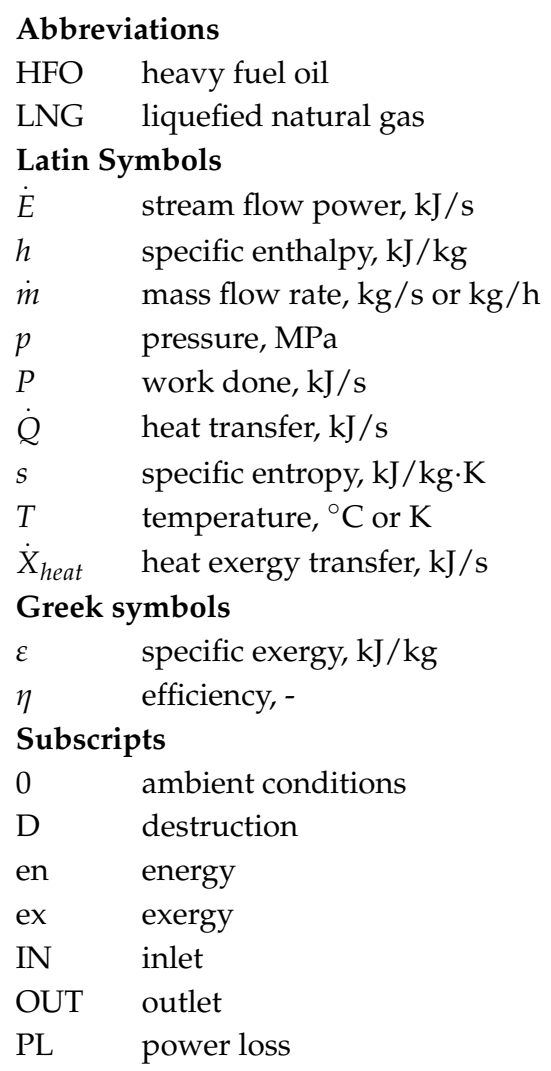

\section{Appendix A.}

\section{A.1. Measuring Equipment Main Characteristics}

Table A1. Main propulsion propeller revolutions: Kyma Shaft Power Meter (KPM-PFS) [48].

\begin{tabular}{ccc}
\hline Accuracy & Absolute & Relative \\
\hline Torque & $< \pm 0.5 \%$ & $< \pm 0.5 \%$ \\
Thrust & $< \pm 5.0 \%$ & $< \pm 5.0 \%$ \\
Revolution & $< \pm 0.1 \%$ & $< \pm 0.1 \%$ \\
Power & $< \pm 0.5 \%$ & $< \pm 0.5 \%$ \\
\hline
\end{tabular}

Power is calculated from measured torque and revolutions.

\section{A.1.1. Steam and Condensate (According to Figure 3)}

Steam mass flow-air heater inlet (STREAM 1)

Yamatake JTD960A—Differential Pressure Transmitter [49].

\begin{tabular}{cc}
\hline Measuring range: & 0.25 to $14 \mathrm{MPa}$ \\
Setting span: & -100 to $14 \mathrm{MPa}$ \\
Working pressure range: & $2.0 \mathrm{kPa}$ to $14 \mathrm{MPa}$ \\
\hline
\end{tabular}

\section{Steam pressure-air heater inlet (STREAM 1)}

Yamatake JTG940A-Pressure Transmitter [50].

\begin{tabular}{cc}
\hline Measuring range: & 35 to $3500 \mathrm{kPa}$ \\
Setting span: & -100 to $3500 \mathrm{kPa}$ \\
Working pressure range: & $2.0 \mathrm{kPa}$ to $3500 \mathrm{kPa}$ \\
\hline
\end{tabular}


Steam temperature-air heater inlet (STREAM 1)

Greisinger GTF 601-Pt100-Immersion probe [51].

\begin{tabular}{cc}
\hline Measuring range: & -200 to $+600{ }^{\circ} \mathrm{C}$ \\
Response time: & approx. $10 \mathrm{~s}$ \\
Standard: & $1 / 3$ DIN class B \\
Error ranges: & $\pm\left(0.10+0.00167 \cdot \mid\right.$ in $\left.{ }^{\circ} \mathrm{Cl}\right)$ \\
\hline
\end{tabular}

Condensate mass flow-air heater outlet (STREAM 2)

Yamatake JTD960A—Differential Pressure Transmitter [49].

Condensate pressure-air heater outlet (STREAM 2)

Yamatake JTG940A—Pressure Transmitter [50].

Condensate temperature-air heater outlet (STREAM 2)

Greisinger GTF 401-Pt100-Immersion probe [51].

\begin{tabular}{cc}
\hline Measuring range: & -50 to $+400{ }^{\circ} \mathrm{C}$ \\
Response time: & approx. $10 \mathrm{~s}$ \\
Standard: & DIN class B \\
Error ranges: & $\pm\left(0.30+0.00500 \cdot \mid\right.$ in $\left.{ }^{\circ} \mathrm{Cl}\right)$ \\
\hline
\end{tabular}

A.1.2. Air (according to Figure 3)

Air mass flow-air heater inlet (STREAM 3)

Yamatake JTD930A—Differential Pressure Transmitter [49]

\begin{tabular}{cc}
\hline Measuring range: & 35 to $700 \mathrm{kPa}$ \\
Setting span: & -100 to $700 \mathrm{kPa}$ \\
Working pressure range: & $2.0 \mathrm{kPa}$ to $14 \mathrm{MPa}$ \\
\hline
\end{tabular}

Air pressure-air heater inlet (STREAM 3)

Yamatake JTG940A—Pressure Transmitter [50]

Air temperature-air heater inlet (STREAM 3)

Greisinger GTF 401-Pt100-Immersion probe [51]

Air mass flow-air heater outlet (STREAM 4)

Yamatake JTD930A—Differential Pressure Transmitter [49]

Air pressure-air heater outlet (STREAM 4)

Yamatake JTG940A—Pressure Transmitter [50]

Air temperature-air heater outlet (STREAM 4)

Greisinger GTF 401-Pt100-Immersion probe [51]

\section{References}

1. Erdem, H.H.; Akkaya, A.V.; Cetin, B.; Dagdas, A.; Sevilgen, S.H.; Sahin, B.; Teke, I.; Gungor, C.; Atas, S. Comparative energetic and exergetic performance analyses for coal-fired thermal power plants in Turkey. Int. J. Therm. Sci. 2009, 48, 2179-2186. [CrossRef]

2. Ahmadi, G.R.; Toghraie, D. Energy and exergy analysis of Montazeri Steam Power Plant in Iran. Renew. Sustain. Energy Rev. 2016, 56, 454-463. [CrossRef] 
3. Mitrović, D.; Živković, D.; Laković, M.S. Energy and Exergy Analysis of a 348.5 MW Steam Power Plant. Energy Sources Part A 2010, 32, 1016-1027. [CrossRef]

4. Adibhatla, S.; Kaushik, S.C. Energy and exergy analysis of a super critical thermal power plant at various load conditions under constant and pure sliding pressure operation. Appl. Therm. Eng. 2014, 73, 51-65. [CrossRef]

5. Regulagadda, P.; Dincer, I.; Naterer, G.F. Exergy analysis of a thermal power plant with measured boiler and turbine losses. Appl. Therm. Eng. 2010, 30, 970-976. [CrossRef]

6. Uysal, C.; Kurt, H.; Kwak, H.Y. Exergetic and thermoeconomic analyses of a coal-fired power plant. Int. J. Therm. Sci. 2017, 117, 106-120. [CrossRef]

7. Annaratone, D. Steam Generators-Description and Design; Springer: Berlin, Germany, 2008.

8. Woodruff, E.; Lammers, H.; Lammers, T. Steam Plant Operation, 8th ed.; McGraw-Hill Professional: New York, NY, USA, 2004.

9. Kitto, J.B.; Stultz, S.C. Steam/Its Generation and Use, 41st ed.; The Babcock \& Wilcox Company: Akron, OH, USA, 2005.

10. Vuthaluru, H.B.; French, D.H. Investigations into the air heater ash deposit formation in large scale pulverised coal fired boiler. Fuel 2015, 140, 27-33. [CrossRef]

11. Ganapathy, V. Industrial Boilers and Heat Recovery Steam Generators-Design, Applications, and Calculations; Marcel Dekker, Inc.: New York, NY, USA, 2003.

12. Sarkar, D.K. Thermal Power Plant_Design and Operation; Elsevier Inc.: Amsterdam, The Netherlands, 2015.

13. Annaratone, D. Handbook for Heat Exchangers and Tube Banks Design; Springer: Berlin, Germany, 2010. [CrossRef]

14. Ganapathy, V. Steam Generators and Waste Heat Boilers for Process and Plant Engineers; CRC Press, Taylor \& Francis Group: Boca Raton, FL, USA, 2015.

15. Jin, D.; Zuo, J.; Quan, S.; Xu, S.; Gao, H. Thermohydraulic performance of solar air heater with staggered multiple V-shaped ribs on the absorber plate. Energy 2017, 127, 68-77. [CrossRef]

16. Menasria, F.; Zedairia, M.; Moummi, A. Numerical study of thermohydraulic performance of solar air heater duct equipped with novel continuous rectangular baffles with high aspect ratio. Energy 2017, 133, 593-608. [CrossRef]

17. Sharma, S.K.; Kalamkar, V.R. Experimental and numerical investigation of forced convective heat transfer in solar air heater with thin ribs. Sol. Energy 2017, 147, 277-291. [CrossRef]

18. Sawhney, J.S.; Maithani, R.; Chamoli, S. Experimental investigation of heat transfer and friction factor characteristics of solar air heater using wavy delta winglets. Appl. Therm. Eng. 2017, 117, 740-751. [CrossRef]

19. Kabeel, A.E.; Hamed, M.H.; Omara, Z.M.; Kandeal, A.W. Solar air heaters: Design configurations, improvement methods and applications-A detailed review. Renew. Sustain. Energy Rev. 2017, 70, 1189-1206. [CrossRef]

20. Main Boiler (MB-4E-KS) Steam Air Heater; DongHwa Entec, Mitsubishi Heavy Industries, Ltd., Nagasaki Shipyard \& Machinery Works: Nagasaki, Japan, 2004.

21. Marine Machinery and Engine 2013; Mitsubishi Heavy Industries: Nagasaki, Japan, 2013; Available online: https:/ / www.mhi-mme.com/lib/cp_catalogue_e.pdf (accessed on 15 June 2016).

22. Main Boilers Operation and Maintenance Instructions (MB-4E-KS); Mitsubishi Heavy Industries, Ltd., Nagasaki Shipyard \& Machinery Works: Nagasaki, Japan, 2005.

23. Pourramezan, M.; Kahrom, M.; Passandideh-Fard, M. Numerical investigation on the lifetime decline of burners in a wall-fired dual-fuel utility boiler. Appl. Therm. Eng. 2015, 82, 141-151. [CrossRef]

24. Kaushik, S.C.; Siva Reddy, V.; Tyagi, S.K. Energy and exergy analyses of thermal power plants: A review. Renew. Sustain. Energy Rev. 2011, 15, 1857-1872. [CrossRef]

25. Hafdhi, F.; Khir, T.; Yahyia, B.A.; Brahim, B.A. Energetic and exergetic analysis of a steam turbine power plant in an existing phosphoric acid factory. Energy Convers. Manag. 2015, 106, 1230-1241. [CrossRef]

26. Taner, T. Optimisation processes of energy efficiency for a drying plant: A case of study for Turkey. Appl. Therm. Eng. 2015, 80, 247-260. [CrossRef]

27. Tan, H.; Zhao, Q.; Sun, N.; Li, Y. Enhancement of energy performance in a boil-off gas re-liquefaction system of LNG carriers using ejectors. Energy Convers. Manag. 2016, 126, 875-888. [CrossRef]

28. Mrzljak, V.; Poljak, I.; Medica-Viola, V. Dual fuel consumption and efficiency of marine steam generators for the propulsion of LNG carrier. Appl. Therm. Eng. 2017, 119, 331-346. [CrossRef] 
29. Kanoğlu, M.; Çengel, Y.A.; Dincer, I. Efficiency Evaluation of Energy Systems; Springer Briefs in Energy; Springer: Berlin, Germany, 2012. [CrossRef]

30. Aljundi, I.H. Energy and exergy analysis of a steam power plant in Jordan. Appl. Therm. Eng. 2009, 29, 324-328. [CrossRef]

31. Elsafi, A.M. Exergy and exergoeconomic analysis of sustainable direct steam generation solar power plants. Energy Convers. Manag. 2015, 103, 338-347. [CrossRef]

32. Zisopoulos, F.K.; Moejes, S.N.; Rossier-Miranda, F.J.; Van der Goot, A.J.; Boom, R.M. Exergetic comparison of food waste valorization in industrial bread production. Energy 2015, 82, 640-649. [CrossRef]

33. Nazari, N.; Heidarnejad, P.; Porkhial, S. Multi-objective optimization of a combined steam-organic Rankine cycle based on exergy and exergo-economic analysis for waste heat recovery application. Energy Convers. Manag. 2016, 127, 366-379. [CrossRef]

34. Ahmadi, G.; Toghraie, D.; Azimian, A.; Ali Akbari, O. Evaluation of synchronous execution of full repowering and solar assisting in a $200 \mathrm{MW}$ steam power plant, a case study. Appl. Therm. Eng. 2017, 112, 111-123. [CrossRef]

35. Dincer, I.; Midilli, A.; Kucuk, H. Progress in Exergy, Energy and the Environment; Springer: Basel, Switzerland, 2014; pp. 15-22.

36. Vandani, A.M.K.; Bidi, M.; Ahmadi, F. Exergy analysis and evolutionary optimization of boiler blowdown heat recovery in steam power plants. Energy Convers. Manag. 2015, 106, 1-9. [CrossRef]

37. Taner, T.; Sivrioglu, M. Energy-exergy analysis and optimisation of a model sugar factory in Turkey. Energy 2015, 93, 641-654. [CrossRef]

38. Mrzljak, V.; Poljak, I.; Mrakovčić, T. Energy and exergy analysis of the turbo-generators and steam turbine for the main feed water pump drive on LNG carrier. Energy Convers. Manag. 2017, 140, 307-323. [CrossRef]

39. Szargut, J. Exergy Method-Technical and Ecological Applications; WIT Press: Southampton, UK, 2004.

40. Lemmon, E.W.; Huber, M.L.; McLinden, M.O. NIST Reference Fluid Thermodynamic and Transport Properties-REFPROP; Version 8.0, User's Guide; National Institute of Standards and Technology: Boulder, CO, USA, 2007.

41. Mrzljak, V.; Poljak, I.; Medica-Viola, V. Efficiency and losses analysis of low-pressure feed water heater in steam propulsion system during ship maneuvering period. Sci. J. Marit. Res. 2016, 30, 133-140.

42. Cengel, Y.; Boles, M. Thermodynamics an Engineering Approach, 8th ed.; McGraw-Hill Education: New York, NY, USA, 2015.

43. Mrzljak, V.; Poljak, I.; Medica-Viola, V. Energy and Exergy Efficiency Analysis of Sealing Steam Condenser in Propulsion System of LNG Carrier. Our Sea Int. J. Marit. Sci. Technol. 2017, 64, 20-25. [CrossRef]

44. Moran, M.; Shapiro, H.; Boettner, D.D.; Bailey, M.B. Fundamentals of Engineering Thermodynamics, 7th ed.; John Wiley and Sons, Inc.: Hoboken, NJ, USA, 2011.

45. Dincer, I.; Rosen, M.A. Exergy Energy, Environment and Sustainable Development, 2nd ed.; Elsevier: Amsterdam, The Netherlands, 2013; pp. 31-49. ISBN 978-0-08-097089-9.

46. Kopac, M.; Hilalci, A. Effect of ambient temperature on the efficiency of the regenerative and reheat Catalagzi power plant in Turkey. Appl. Therm. Eng. 2017, 27, 1377-1385. [CrossRef]

47. Ameri, M.; Ahmadi, P.; Hamidi, A. Energy, exergy and exergoeconomic analysis of a steam power plant: A case study. Int. J. Energy Res. 2009, 33, 499-512. [CrossRef]

48. Kyma Performance Monitoring. Available online: http://hwt0346.51software.net/uploadfiles/20111129195 81355.pdf (accessed on 30 August 2017).

49. JTD Series of Differential Pressure Transmitters. Available online: http://www.krtproduct.com/krt_Picture /sample/1_spare\%20part/yamatake/Fi_ss01/SS2-DST100-0100.pdf (accessed on 26 August 2017).

50. JTG Series of Pressure Transmitters. Available online: http://http://www.industriascontrolpro.com/fichat/ SS2-DST400-0100.pdf (accessed on 26 August 2017).

51. SUITABLE PT100 MEASURING PROBE (4-WIRE). Available online: https:/ / www.greisinger.de/files/upl oad/en/produkte/kat/k16_011_EN_oP.pdf (accessed on 28 August 2017).

(C) 2018 by the authors. Licensee MDPI, Basel, Switzerland. This article is an open access article distributed under the terms and conditions of the Creative Commons Attribution (CC BY) license (http://creativecommons.org/licenses/by/4.0/). 